\title{
MOVING EVENT AND MOVING PARTICIPANT IN ASPECTUAL CONCEPTIONS
}

\section{Katsunobu Izutsu ${ }^{1}$}

Izutsu, K. Moving event and moving participant in aspectual conceptions // Lege artis. Language yesterday, today, tomorrow. The Journal of University of SS Cyril and Methodius in Trnava. Warsaw: De Gruyter Open, 2013, vol. 1 (1), June 2016. - p. 116-162. DOI: 10.1515/lart-2016-0003 ISSN 2453-8035

\begin{abstract}
This study advances an analysis of the event conception of aspectual forms in four East Asian languages: Ainu, Japanese, Korean, and Ryukyuan. As earlier studies point out, event conceptions can be divided into two major types: the moving-event type and the moving-participant type, respectively. All aspectual forms in Ainu and Korean, and most forms in Japanese and Ryukyuan are based on that type of event conception. Moving-participant oriented Ainu and movingevent oriented Japanese occupy two extremes, between which Korean and Ryukyuan stand. Notwithstanding the geographical relationships among the four languages, Ryukyuan is closer to Ainu than to Korean, whereas Korean is closer to Ainu than to Japanese.
\end{abstract}

Keywords: aspect, phase, event conception, Ainu, Japanese, Korean, Ryukyuan.

\section{Introduction}

This article analyzes the event conception of aspectual expressions in four East Asian languages (Ainu, Japanese, Korean, and Ryukyuan) and advances a typological

\footnotetext{
${ }^{1}$ I am deeply indebted to Rumiko Shinzato for her profound knowledge of Ryukyuan as well as Japanese and of cognitivefunctional insights into the grammar and meaning, and to Yongtaek Kim for his thoughtful observations on discoursepragmatic phenomena in Korean and Japanese. I would like to express my sincere gratitude to two anonymous reviewers of Lege Artis for their suggestions and comments. I am also very thankful to Anna Bordilovskaya for helping me with the résumé in Russian and to Toshiko Yamaguchi and Magnús Pétursson with those in German and French. Any mistakes and shortcomings in the present study are entirely my responsibility, however. Part of the present article was orally presented at the 12th Conceptual Structure, Discourse, and Language conference, held in Santa Barbara on 5 November 2014. I am very grateful to Takeshi Koguma and Mitsuko Narita Izutsu for asking helpful clarifying questions and providing useful comments on the paper presented at the conference. I would also like to express my sincere thanks to Kaoru Horie and some other people in the audience for their questions and comments on the presentation in the conference.
} 
perspective in terms of 'moving event' and 'moving participant'. ${ }^{1}$ Event conceptions generally divide themselves into two major types, which largely correspond to Lakoff and Johnson's (1999: 196) "Location Event-Structure" and "Object Event-Structure" metaphors, as discussed in Section 2. In the first type, an event is conceived of as a location that a participant comes into or goes out of (moving-participant type), but in the second, a participant is viewed as a location in which an event occurs (movingevent type).

Whereas the moving-participant type of event conception is predominant in the aspectual senses of the four languages, the moving-event type is also dominant in Japanese and Ryukyuan. Ainu and Korean are comparable because their aspectual forms are all based on the moving-participant type of event conception. On the other hand, Ryukyuan and Ainu are similar in that they have an aspectual form with an existential verb of absence as well as ones with an existential verb of presence. The analysis also shows that the two types of event conceptions do not always serve as figure-ground reversals of each other, even though they often do, as Lakoff and Johnson (1999) point out. For instance, aspectual forms based on the movingparticipant type of event conception (e.g., Japanese resultative ake-te ar(-u) 'have (it) opened') do not concur with those based on the moving-event type (e.g., Japanese perfect V-te i-ru 'have Ved'). However, some phasic expressions based on the movingevent type (e.g., Japanese and Korean verbs for 'start') can concur with aspectual forms based on the moving-participant type (e.g., the progressive or resultative sense of Japanese V-te-iru and Korean V-go issda), as will be detailed in Section 5.3.

The four languages are well known to have two-verb constructions with a "modality verb" (Givón 1984, 1990) as the second verb, which are roughly grouped under the name of "converb construction" (Shibatani 2003: 263). Aspectual forms of the languages identifiable as "continuative", "progressive", "perfect", "resultative", "inceptive", and "terminative" (Bybee et al. 1994; Comrie 1976; Freed 1979; Smith 
1991) mostly derive from such constructions and have been grammaticized or grammaticalized to greater or lesser degrees, as illustrated in (1). ${ }^{2}$ In some cases, the relevant forms are more likely analyzed as verbs and their suffixes, as in (1b) and (1d), while in others, they look more like two verbs jointed by connective particles (converbalizers), as in (1a) and (1c).

$$
\begin{aligned}
& \text { a. } \quad k \quad \text { kor an. (Ainu progressive) } \\
& \text { come conv be.present } \\
& \text { '(He) is coming.' }
\end{aligned}
$$

b. yuki-ga huri-hazimeta. (Japanese inceptive) snow-NOM fall-start: PST 'It is snowing.'

c. kadi nee(ra)n. (Ryukyuan resultative) eat:CONV be.absent

'(I) have eaten (it) up.'

d. da meog-eo-beoryeossda. (Korean terminative)

all eat-CONV-throw.away:CONV:PST

'(I) have eaten (it) all.'

In terms of event conception and historical development, some of the constructions are compositionally ambiguous; they can be analyzed as either a converb/modality-verb construction or a verb with a nominalized verb (verbal noun) complement: schematically represented as $\mathrm{X}_{\text {subj }}\left(\mathrm{Y}_{\text {obj }}\right) \mathrm{V}_{\text {conv }} \mathrm{V}_{\text {mod }}$ and $\mathrm{X}_{\text {subj }}\left(\mathrm{Y}_{\text {obj }}\right) \mathrm{V}_{\text {nom }} \mathrm{V}_{2}$, respectively. Moreover, the notional subject (and object) of $\mathrm{V}_{\bmod }$ in the converb/modality-verb construction can often be lexically underdetermined. If $\mathrm{V}_{\bmod }$ is intransitive as in (1a) and (1c), its notional (unexpressed) subject can correspond to the subject or object of $\mathrm{V}_{\text {conv }}$, or else to the event designated in $\mathrm{V}_{\text {conv }}$. In (1a), the subject of an 'be present' corresponds to that of $e k$ 'come' or the event designated in the converb 'coming.' In (1c), the subject of nee(ra)n 'be absent' corresponds either to the object, 
not subject, of kadi 'eat:CONV' or to the event designated in the converb 'eating.' If $\mathrm{V}_{\text {mod }}$ is transitive as in (1b) and (1d), its subject coincides with the subject of $\mathrm{V}_{\text {conv }}$, but its object can correspond to the object or the designated event of $\mathrm{V}_{\text {conv. }}$ In (1d), for instance, the object of beoryeossda 'threw away' corresponds to either the object of meog-eo 'eat-CONV' or the event of 'eating.'

The $\mathrm{V}_{\text {mod }}$ and $\mathrm{V}_{2}$ in these aspectual forms confine themselves to a narrowly defined notional group of verbs (Chiri 1942; Handa 1999; Izutsu 1999; Lee 1993; Soga 1983): their essential meaning involves the "presence" or "absence" of "objects" or "activities" (Tomasello 1992: 44, 60). These notions bear a close relationship with notional characterizations of aspectual concepts: the beginning, continuation, and end of an event, encoded in inceptive, continuative, and terminative forms. In "localist" approaches, each concept is defined in terms of a participant's "going into" and "coming out of a situation" (Brinton 1988: 112). Aspectual forms can also be understood as making a partial reference to the "temporal structure of events": "initial and final points" and "preliminary", "internal", and "resultant" stages (Smith 1991: 23). These approaches can be viewed as presupposing the moving-participant type of event conception (or what Lakoff and Johnson calls Location Event-Structure metaphor).

As will be demonstrated in Section 3, however, the aspectual concepts can be characterized in terms of the moving-event as well as moving-participant type of event conception; the senses of inceptive, continuative, and terminative forms can be conceptually analyzed as the appearance, presence, and disappearance of either an event or its participant. As noted above, the notional subject of intransitive $V_{\text {mod }}$ and the object of transitive $\mathrm{V}_{\text {mod }}$ in the converb/modality-verb construction can vary in a certain range of referents; each aspectual form is accordingly based on one type or the other (some seemingly on both), as argued in Section 4. 
A comparison of aspectual forms in the four languages offers a typological perspective on aspectual construal of event conception, as argued in Section 5. Ainu and Korean aspectual forms put more focus on event participants than Japanese and Ryukyuan forms do. The pronominal affixes on verbs in Ainu reflect this distinct characteristic; e.g., the existential verb in the aspectual forms is marked with a pronominal affix that agrees in person and number with the participant in the event encoded in the converb. By contrast, Japanese and Ryukyuan forms are more inclined to emphasize the presence of an event or its resultant state rather than that of its participant; the existential verb in aspectual forms does not necessarily agree in animacy with the participant in the event encoded in the converb. The absence (as well as presence) of an event participant can be focused on in Ainu and Ryukyuan forms, while it is not the case in Japanese and Korean forms. These observations imply a typological continuum in which moving-participant oriented Ainu and moving-event oriented Japanese occupy the two extremes with Korean and Ryukyuan in between. Notwithstanding their geographical relationships, Ryukyuan is closer to Ainu than to Korean, while Korean is closer to Ainu than to Japanese.

\section{Major types of event conceptions}

As we experience events, states, actions, or activities, we conceive of ourselves as either facing/encountering or undergoing/going through such experiences. What we face or encounter is supposed to be an object rather than a location, whereas what we undergo or experience is more likely viewed as a location than an object. This means that events, states, actions, and activities can all be conceptualized as either objects or locations. Lakoff and Johnson's Location Event-Structure and Object Event-Structure metaphors reflect this duality of the way we conceptualize events, states, actions, and activities. 


\subsection{Lakoff and Johnson's five metaphors for event conceptions}

Lakoff and Johnson (1999) observe that our understanding of events comes mostly from the "Location Event-Structure" and "Object Event-Structure" metaphors. These differ "in that one conceptualizes events in terms of locations, the other, in terms of objects" (p.179). In the Location Event-Structure metaphor, states are conceived of as locations, and changes (events) are, as movement from one location to another, as illustrated in (2a-b). ${ }^{3}$

(2) a. I'm in love. She's out of depression. He's on the edge of madness. He's in a deep depression. She's close to insanity. We're far from safety.

(Lakoff \& Johnson 1999: 180; emphasis original)

b. I came out of my depression. He went crazy. (...) She entered a state of euphoria. He fell into a depression. (...) In the sun, the clothes went from wet to dry in an hour. The clothes are somewhere between wet and dry.

(ibid.: 183; emphasis original)

In the Object Event-Structure metaphor, by contrast, attributes (which correspond to states in the Location Event-Structure metaphor) are conceptualized as possessions, and changes (events) are conceptualized as movements of possession (acquisitions or losses), as exemplified in (3).

(3) I have a headache. (The headache is a possession.)

I got a headache. (Change is acquisition-motion to.)

My headache went away. (Change is loss-motion from.)

Lakoff \& Johnson (1999: 196; emphasis original)

Lakoff \& Johnson (1999: 203) add three more metaphors that use some of the same primary metaphors used in the Location Event-Structure metaphor. One is the "Moving 
Activity" metaphor, in which activities are conceptualized as "things that move" (ibid.), as illustrated in (4).

(4) The project has slowed to a crawl.

The book is moving right along.

The writing is moving right along.

(Lakoff \& Johnson 1999: 203; emphasis original)

The others are the "Action-Location" metaphor (p.204), by which an action is identified as 'being in a location' as exemplified in (5), and the "Existence as Location" metaphor (p. 205), according to which "we speak of things being in existence, coming into existence and going out of existence" (p. 206). As an example of this latter metaphor, Lakoff and Johnson point out: "Wishing to live can be expressed as wishing to be here for a long time" (p. 206).

(5) I'm leaning toward leaving. They pushed him into running for president. (...) She's close to resigning. She backed away from resigning. She came near to resigning. He's inching toward invading another country.

(Lakoff \& Johnson 1999: 204; emphasis original)

Lakoff and Johnson (1999: 195) argue that the difference between the Location EventStructure and Object Event-Structure metaphors "can be seen as a figure-ground shift", as is the case, they claim, of the contrast between "the Moving Time" and "Moving Observer" metaphors of time (1999: 148-149). ${ }^{4}$ They illustrate such event-structure duality succinctly with the contrast in (6), noting that "trouble is conceptualized as a location you are in" in the first case but "as an object you can have" in the second (1999: 195).

(6) Harry's in trouble. (States Are Locations) 
Harry has trouble. (Attributes Are Possessions)

\subsection{Location or object: dual conceptions of events and states}

Lakoff and Johnson's three additional metaphors for events also manifest the dual conceptions (the two ways we conceptualize events, states, actions, and activities). As noted above, the Moving Activity metaphor conceptualizes activities as movements, but the entity assumed to move can be either an activity itself (e.g., 'writing' in The writing is moving right along) or its participant (e.g., 'the book' in The book is moving right along), both illustrated in (4). Similarly, while the actions in the Action-Location metaphor and the state of existence in the Existence as Location metaphor are conceived of as locations, the entity assumed to act or exist in these metaphors can be an event (e.g., 'the customary action' in The custom came into [was in] existence) as well as its participant (e.g., 'the dinosaur' in The dinosaur came into [was in] existence). Thus, the activities, actions, and states in these three metaphors can amount to the attributes in the Object Event-Structure metaphor as well as to the states and changes in the Location Event-Structure metaphor.

If we adopt "event/state" as a cover term for events, states, actions, activities, and attributes on the one hand, and its "participant" as one for the entities that undergo the events, states, actions, activities, and attributes on the other, then Lakoff and Johnson's event metaphors can be analyzed anew as conceptualizing event/state and/or its participant as an object that moves to or from a location, as shown in Table 1. The Location Event-Structure metaphor envisages an event/state as a location to and from which its participant moves, whereas the Object Event-Structure metaphor envisions an event/state as an object that moves to and from its participant. 
Table 1. Object and location entities in metaphors for events

\begin{tabular}{|l|c|c|}
\hline & object & location \\
\hline $\begin{array}{l}\text { Location Event-Structure metaphor } \\
\text { (e.g., Harry's in trouble.) }\end{array}$ & participant & event/state \\
\hline $\begin{array}{l}\text { Object Event-Structure metaphor } \\
\text { (e.g., Harry has trouble.) }\end{array}$ & event/state & participant \\
\hline $\begin{array}{l}\text { Moving Activity metaphor } \\
\text { (e.g., The book [writing] is moving right along.) }\end{array}$ & participant [event/state] & event/state \\
\hline $\begin{array}{l}\text { Action-Location metaphor } \\
\text { (e.g., The machine [rain] came near to stopping.) }\end{array}$ & participant [event/state] & event/state \\
\hline $\begin{array}{l}\text { Existence as Location metaphor } \\
\text { (e.g., The dinosaur [custom] came into existence.) }\end{array}$ & participant [event/state] & event/state \\
\hline
\end{tabular}

Unlike the Location Event-Structure and Object Event-Structure metaphors, however, the other metaphors allow the entities conceptualized as objects and locations to be both events/states. In these cases, the event/state participants are often metonymically regarded as those events/states themselves; The book is moving right along in (4) for instance means The writing of the book is moving right along. Such metonymy or conceptual duality can be responsible for grammaticalization of aspectual expressions as will be discussed below.

If the object and location involved in the metaphors are represented by a globe and box, respectively, as in Figure 1(a), the event conception of the Location Event-Structure metaphor can be diagramed as in Figure 1(b), where the box labeled "E" and the globe labeled "P" correspond to an event/state and (one of) its participant(s), respectively. In contrast, the conception of the Object Event-Structure metaphor can be diagramed as in Figure 1(c), in which the globe labeled "E" stands for an event/state, and the box labeled "P", for (one of) its participant(s) (typically the subject entity).

(a)

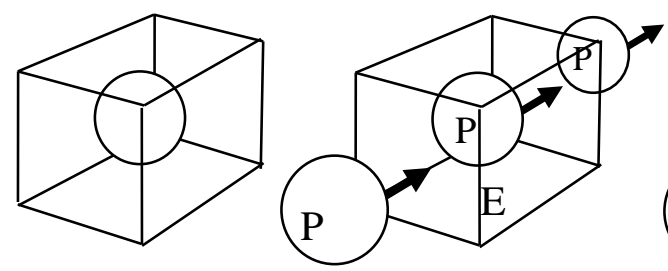

(c)

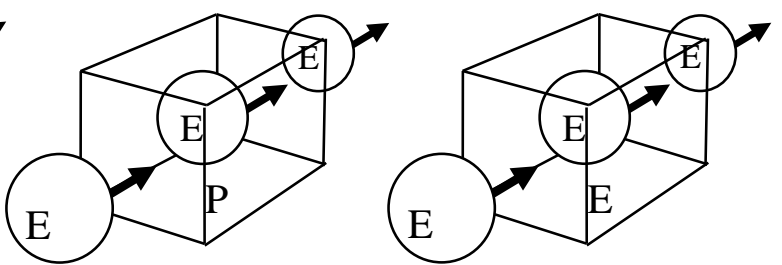

Figure 1. Conceptualizations of event-structure metaphors 
The event conception of the Moving Activity, Action-Location, and Existence as Location metaphors can be diagramed as in Figure 1(d) when events/states are conceived of as objects as in The writing is moving right along, whereas it can be diagramed as in Figure 1(b) when event/state participants are identified as objects as in The book is moving right along. The three metaphors might be characterized more appropriately as the latter because Lakoff and Johnson (1999: 203) treat them as "Variations on the Location Event-Structure Metaphor". However, they can be understood in terms of either the moving-event or moving-participant type of event conceptions discussed below.

\subsection{Moving-event and moving-participant conceptions of events/states}

The above analysis helps to reorganize Lakoff and Johnson's five metaphors for events into two: moving-event/state and moving-participant types. The Location EventStructure metaphor is based on the moving-participant type of event conception, and the Object Event-Structure metaphor is on the moving-event/state type. By contrast, the other three metaphors are not uniformly classified into one or the other but can be treated as either according to whether the relevant moving entity is an event/state or whether it is its participant(s).

Whereas Lakoff and Johnson (1999: 179) define locations as "interiors of bounded regions in space", they do not seem to give such a specific definition of objects. However, the usage in the five metaphors suggests that the term "object" refers to a thing or entity that can move into, be in, or move out of, a location. As instantiated in (4), events/states as well as their participants can be conceptualized as objects in the Moving Activity, Action-Location, and Existence as Location metaphors. Such events/states (e.g., 'writing') can be viewed as locations, as instantiated by the first and second sentences in (4); they are supposed to accommodate their participants (e.g., 'the book'), as diagramed in Figure 2(a). In the meantime, events or states can be recognized as objects that move into or out of another event/state ('moving right along'), as 
exemplified by the third sentence in (4), which can be diagramed in Figure 2(b). The object status of the events and states is represented by the small globe labeled " $\mathrm{E}_{1}$ " here, which corresponds to the box labeled "E" (location status) in Figure 2(a). The dotted lines connecting the globe and box represent the correspondence between them, indicating the dual status of events/states.

(a) Moving Participant

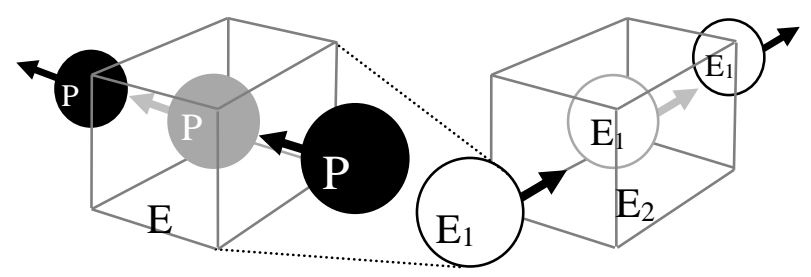

(b) Moving Event/State I

(c) Moving Event/State II

Figure 2. The dual status of moving events/states

As instantiated in (3), repeated below, the moving events/states can also be conceived of as moving into and out of a participant. This conception can be diagramed as in Figure 2(c), where the larger globe labeled "P" stands for a participant of the event represented by the small globe labeled " $E_{1}$ ". Each sentence in (3) conceptualizes the event of headache as being in, moving in, and going away from the speaker. The dual status of the moving events/states implies that the three additional metaphors (Moving Activity, Action-Location, and Existence as Location) can be grounded on either the moving-event/state or the moving-participant type of event conception. In the discussion below, these two types will be referred to simply as "moving-event" and "moving-participant" conceptions.

(3) I have a headache. (The headache is a possession.)

I got a headache. (Change is acquisition-motion to.)

My headache went away. (Change is loss-motion from.)

Lakoff \& Johnson (1999: 196; emphasis original) 


\section{Moving-event/participant conceptions in aspectual meanings}

\subsection{Dual conceptions of events in aspectual meanings}

The conceptualizations encoded in various aspectual expressions can also be analyzed in terms of moving-event and moving-participant conceptions. What are called "inceptive", "ingressive", or "inchoative" expressions (Freed 1979; Givón 1984; 1990; Smith 1991; Soga 1983) like He began to read a book can presuppose either type of event conception. In one type, the event of reading is conceived of as coming into being where the participants 'he' and 'a book' are. This type of event conception can be seen as instantiating a moving-event conception. At the same time, the participants 'he' and 'a book' are conceived of as moving into the event of reading. This can be viewed as an instantiation of moving-participant conception.

Expressions called "progressive" or "continuative" (Bybee et al. 1994; Comrie 1976; Dahl 1985; Smith 1991) like He is reading a book can also be conceptually described in two ways. In one type of event conception, the event of reading is conceived of as having come and not yet left where the participants 'he' and 'a book' are. This can be recognized as an instance of moving-event conception. Contrariwise, the participants 'he' and 'a book' can be conceived of as having moved into, and not yet moved out of, the event of reading. This can be seen as a moving-participant conception.

Similarly, "terminative", "resultative", "anterior", or "perfect" expressions (Bybee et al. 1994; Comrie 1976; Dahl 1985; Smith 1991) like He has read a book can be described in the same way. In one type of event conception, the event of reading is conceived of as having moved out of where the participants 'he' and 'a book' are, usually leaving a resultant state there. This amounts to a moving-event conception. On the other hand, the participants 'he' and 'a book' can also be understood as having gone through the event of reading. This corresponds to a moving-participant conception. 


\subsection{Dominant type of event conception in aspectual expressions}

As demonstrated above, the moving-event type of event conception assumes that an event traverses its participant(s), while the moving-participant type of event conception presupposes that a participant traverses an event. Logically, either type of conception is possible in the meaning of aspectual expressions. However, the meaning of the English progressive and perfect constructions could be traced back to one or the other type of event conception in literal or historical terms.

The progressive construction, be $\mathrm{V}$-ing, is considered to have developed from such a locative construction as exemplified in (7), in which be is understood as having once designated the presence of the subject referent in the event encoded in V-ing (Bybee et al. 1994: 132; Comrie 1976: 99; Jespersen 1949: 168). Bybee et al. (1994: 135) even say that what the English progressive conveys "seems to be directly derivable from a locative source, from a meaning 'the subject is in the midst of doing something'".

(7) a. He is on hunting.
b. He was a-coming home.

(Bybee et al. 1994: 132)

In the contemporary usage and meaning of the construction, however, be could be more naturally analyzed as designating the presence of the event encoded in V-ing rather than that of its participant. This understanding is more in line with Langacker's (2008: 126) position that be "imposes its temporality" on the atemporal relation encoded in the participle that follows it. The essential function of be is to indicate the presence of a relation (instantiated as an event, state, etc.) in the temporal domain.

The historical or locative meaning of the construction assumes that the event participant encoded in the subject has moved and is still in the event encoded in the participle, while the generalized sense of progressive prefers the conception that the 
event comes into being and is still present with its participant(s). The scenario of constructional development and notional change noted above suggests to us that the event conception encoded in the progressive construction has developed, or at least is developing, from the moving-participant to moving-event type.

The perfect construction, on the other hand, developed out of such a resultative construction as illustrated in (8) (Bybee et al. 1994: 68; Traugott 1972), where have designates the presence in the subject referent's possession or "dominion" (Langacker 1991: 170) of the object referent being in the (resultant) state encoded in the past participle.

(8) Ic hæfde hine gebundenne.

'I had him in a state of being bound.'

(Bybee et al. 1994: 68)

In the contemporary perfect meaning, however, have can be viewed as designating the presence of (some residue of) an event rather than its participant(s). As Comrie (1976: 52) puts it, "the perfect indicates the continuing present relevance of a past situation"; the relevance of the past event encoded in the past participle is supposed to come into being and to still exist in the present situation. Typically, the relevance that exists in the present state corresponds to the resultant ("affecting") state of the event ("dynamic situation") encoded in the past participle, as Bybee et al. (1994) point out about the resultative sense:

In the most common case, the resultative sense is the outcome of the combination of the stative auxiliary, which provides the sense of a present state, and the past and/or passive participle, which signals a dynamic situation which occurred in the past and is seen as affecting the object of the transitive verb or the subject of the intransitive (Bybee et al. 1994: 67-68). 
The conceptual development from the original resultative to perfect construction can also be viewed as a shift from a moving-participant to a moving-event conception. In the resultative construction, the referent encoded in the object of the transitive verb or the subject of the intransitive is envisaged as coming into, and still being in, the resultant state evoked in the past participle. In the perfect construction, by contrast, such a resultant state is envisioned as coming into being and still being with the subject referent. $^{5}$

As far as the progressive and perfect constructions are concerned, English exhibits a strong tendency toward a moving-event type of event conception in aspectual meanings. Nevertheless, the moving-participant as well as moving-event type of conception can be viewed as still dominant in the language; the meaning of the progressive is derivable from the locative sense 'the subject referent comes in, and is still in, the event encoded in the present participle", and the meaning of the perfect presupposes that the referent of the subject (of the intransitive verb) or object (of the transitive) comes in, and is still in, the resultant state of the event encoded in the past participle.

\section{Aspectual conceptions of event in four East Asian languages}

4.1 Progressive, resultative, and perfect senses

The present section examines the event conceptions encoded in major aspectual forms in Ainu, Japanese, Korean, and Ryukyuan, listed in (9). Each form is labeled with the capital letter of language name and a number like A1, A2, and A3 for Ainu aspectual expressions through R1, R2, and R3 for Ryukyuan expressions.

(9) Ainu: $\quad$ V kor an[oka(y)] (A1: progressive $)^{6}$

$\mathrm{V}$ wa an[oka(y)] (A2: resultative)

$\mathrm{V}$ wa isam (A3: resultative)

Japanese: V-t[d]e-iru (J1: progressive/resultative/perfect) 
$\mathrm{V}-\mathrm{t}[\mathrm{d}] \mathrm{e}$-aru (J2: resultative)

Korean: $\quad \mathrm{V}$-go issda (K1: progressive/resultative)

$\mathrm{V}-a[(y) e o]$ issda (K2: resultative)

Ryukyuan: $\mathrm{V}(t[c / d])$-oon (R1: progressive/resultative/perfect)

$\mathrm{V}(t[c / d])$-een (R2: resultative)

$\mathrm{V}(\mathrm{t}[\mathrm{c} / \mathrm{d}])$ i nee(ra)n (R3: resultative)

Interestingly, all the aspectual forms instantiate what Shibatani (2003: 263) refers to as "converb constructions". They consist of a converb (a verb followed by a connective element) and an existential predicate for presence or absence and have a group of senses depending on the transitivity of the converb, as recapped in Table 2, where PROG, RES, and PRF stand respectively for progressive, resultative, and perfect senses.

Table 2. Senses of each aspectual form in four East Asian languages

\begin{tabular}{|c|l|c|c|l|}
\hline & \multicolumn{1}{|c|}{ Ainu } & \multicolumn{1}{|c|}{ Japanese } & \multicolumn{1}{|c|}{ Korean } & \multicolumn{1}{c|}{ Ryukyuan } \\
\hline \multirow{2}{*}{$\mathrm{Vi}_{\text {conv }} \mathrm{V}_{\text {presence }}$} & A1: PROG & J1: PROG/RES/PRF & K1: PROG & R1: PROG/RES/PRF \\
& A2: RES & - & K2: RES & R2: RES \\
\hline \multirow{2}{*}{$\mathrm{Vt}_{\text {conv }} \mathrm{V}_{\text {presence }}$} & A1: PROG & J1: PROG/RES/PRF & K1: PROG/RES & R1: PROG/RES/PRF \\
& A2: RES & J2: RES & - & R2: RES \\
\hline $\mathrm{Vi}_{\text {conv }} \mathrm{V}_{\text {absence }}$ & A3: RES & - & - & R3: RES \\
\hline $\mathrm{Vt}_{\text {conv }} \mathrm{V}_{\text {absence }}$ & A3: RES & - & - & R3: RES \\
\hline
\end{tabular}

(PROG: progressive sense; RES: resultative sense; PRF: perfect sense)

The present study employs progressive, resultative, and perfect to refer to the sense of each aspectual form but they may differ more or less from the definitions of the terms in the major literature (Bybee et al. 1994; Comrie 1976; Dahl 1985). The progressive sense does not diverge so greatly from the definition of the term in the literature; it amounts to the conception in which the event encoded in the converb is itself "ongoing at reference time" (Bybee et al. 1994: 126), as illustrated in Japanese sentence (10a).
a. sensoo-de mainiti hito-ga sin-de iru. (J1: progressive) war-at everyday person-NOM die-CONV be.present 'There are people dying in wars every day.' 
b. suisoo-no sakana-wa subete sin-de iru. (J1: resultative) aquarium-GEN fish-TOP all die-CONV be.present

'The fish in the tank are all dead.'

c. kare-wa zyuu-nen-mae-ni sin-de iru.

(J1: perfect)

he-TOP ten-year-before-at die-CONV be.present

'He (has been dead since he) died ten years ago.'

On the other hand, the resultative and perfect senses both presuppose that the event encoded in the converb has itself ended (either stopped or ceased) and its resultant state remains at reference time, as in Japanese sentences (10b-c). They are distinguished from each other in terms of the specific reference of the relevant existential verb (verb for presence or absence). In the resultative sense, the existential verb refers to the presence or absence of the subject or object referent in the resultant state; this event participant as well as the resultant state exists where the speech event takes place. Thus in (10b), (the dead bodies of) the fish remain in the state after they died in the fish tank. In the perfect sense, the verb focuses on the presence of the resultant state with or without the subject or object referent; in (10c), the state where he is dead persists but he (or his corpse) does not necessarily.

\subsection{Distinct forms for progressive and resultative senses}

First, we look at Ainu expressions A1 and A2, illustrated in (11a-b), respectively. An intransitive V kor an (A1) has a progressive meaning, and so $e k$ kor an means 'he is coming.' Since the verb an agrees with the subject 'he' in person and number, it denotes the presence of the subject entity in the event of coming. ${ }^{7}$

(11) a. ek kor an. (A1: progressive)

come CONV be.present

'(He) is coming.'

(Asai 1969: 788)

b. ek wa an. (A2: resultative) 
come CONV be.present

'(He) has come.'

(Asai 1969: 798)

In contrast, an intransitive $\mathrm{V}$ wa an (A2) has a resultative meaning: 'He has come' or 'He is already here.' Here as well, the verb for presence an agrees with the subject 'he' and therefore the verb indicates the subject referent's presence in the state after the event of coming. The connective wa can be analyzed as what Bybee and Dahl (1989: 86) call "bounder".

Note here that, in these two senses, the relevant event participant is assumed to exist along with the event itself or its resultant state at the time of speech, which makes a clear difference form the perfect sense. The participant is present in the event itself, in the progressive sense, and in its resultant state, in the resultative sense. The event conceptions of the aspectual expressions can thus be viewed as instantiating the moving-participant type of event conception.

Similarly, expressions A1 and A2 with a transitive V convey a progressive and a resultative meaning, respectively, as illustrated in (12a-b). In (12a), k=eramuan kor $k=a n$ means 'I am understanding it more and more,' while $k u=m i$ wa $k=a n$ in (12b) means 'I have put it on' and thus 'I am now wearing it.' ${ }^{8}$ In both sentences, the verb an agrees with the first-person subject 'I', taking the pronominal affix $k(u)=$. In (12a), the verb designates the presence of the speaker in the event of gradual understanding. In (12b), the verb denotes the presence of the speaker in the state after the event of putting it on. These event conceptions can also be viewed as instances of the movingparticipant type of event conception.

$$
\begin{aligned}
& \text { a. k=eramuan kor } k=a n \text {. (A1: progressive) } \\
& \mathrm{I}=\text { understand CONV I-be.present } \\
& \text { 'I am understanding it (more and more).' }
\end{aligned}
$$


b. $\quad k u=m i$ wa $\quad k=a n$. (A2: resultative)

$\mathrm{I}=$ wear CONV I-be.present

'I have put it on.' $\rightarrow$ '(I) have it on.'

(Sato 2008: 199)

The sentence in (13) is an example of Ryukyuan expression R2. This form has a resultative meaning, not a progressive meaning. ${ }^{9}$ The existential verb an, absorbed in een through the contraction koot-i-ya-'an > koot-een (Handa 1999: 108), refers to the presence of the object rather than the subject entity in (13). Thus the sentence conveys that the speaker bought some fine linen weave and she now has it at hand. This event conception is also analyzable as an instantiation of the moving-participant type.

sayun-nunu koot-ee kutu.... (R2: resultative).

linen-weave buy:CONV-TOP:be.present because

'(I) have bought fine linen weave, so....' $\rightarrow$ '(I) have it at hand, so...'

(Handa 1999: 108)

Likewise, Japanese and Korean expressions J2 and K2, illustrated in (14a) and (14b), both have a resultative sense instead of progressive and perfect senses. ${ }^{10}$ In (14a), the window was put in the event of opening and now remains in the resultant state of the event: 'It is open.' The existential verb aru denotes the presence of the object referent in the resultant state of the event encoded in the converb.

(14) a. mado-o ake-te aru. (J2: resultative)

window-ACC open-CONV be.present

'(I) have opened the door.' $\rightarrow$ 'The door is open.'

b. sujoo-eui mulgogi-neun da jug-eo issda. (K2: resultative)

aquarium-GEN fish-TOP all die-CONV be.present

'The fish in the tank are all dead.' 
Likewise in (14b), the subject referents 'the fish' came into the event of dying and are thereafter in the resultant state of the event: 'They are dead.' The existential predicate issda refers to the presence of the event participants in the resultant state. The event conceptions in (14a-b) can also be analyzed as the moving-participant type.

Unlike Japanese and Korean, Ainu and Ryukyuan have a converb construction followed by a predicate for absence, not presence: A3 and R3, exemplified in (15a) and (15b), respectively. In (15a), the verb for absence isam agrees with the third-person object of the converb $k u=k u w a$; accordingly, it denotes the absence of the unexpressed object entity, something to drink, in the state after the event of drinking (Tamura 1996: 246). Likewise in (15b), the predicate neen or neeran denotes the absence of the object entity, something to eat, in the state after the event of eating (Nishioka \& Nakahara 2000: 119). In these constructions, the existential verbs isam, neen, and neeran refer to the absence of a participant rather than an event; they presuppose that something to drink or eat comes in, and then goes out of, the event of eating or drinking. These event conceptions can also be seen as exemplifying the moving-participant type of event conception.

a. $\quad k u=k u \quad$ wa isam. (A3: resultative).

(Tamura 1996: 37)

$\mathrm{I}=$ drink CONV be.absent

' lit.) I drank (it) and (it) is gone.' $\rightarrow$ 'I have drunk (it).'

b. kadi nee(ra)n. (R3: resultative).

(Handa 1999: 396)

eat:CONV be.absent

'(lit.) (I) ate (it) and (it) is gone.' $\rightarrow$ '(I) have eaten (it).'

\subsection{Identical forms for progressive, resultative, and perfect senses}

Japanese aspectual form J1 can convey a progressive, resultative, or perfect sense, as observed in (10) above. The verb for presence, iru, in this form is analyzable as referring to the presence of an event itself or its resultant state rather than its 
participants, because the verb does not agree with the subject entity in animacy in (10b), repeated in (16a). In the main verb use, iru takes animate subjects, as in (16b), while aru takes inanimate subjects, as in (16c).

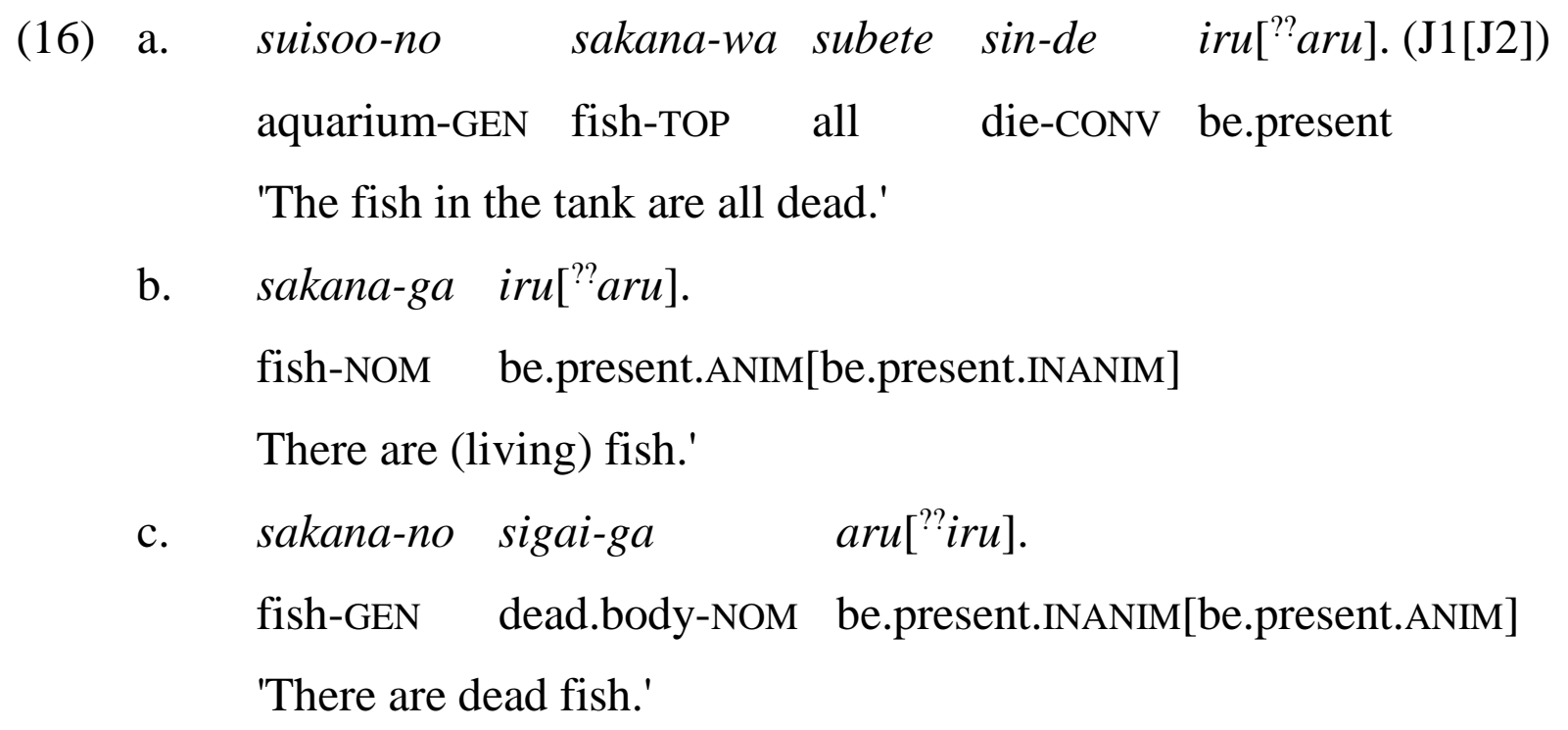

A consideration in this respect, therefore, strongly suggests that iru in (16a) refers to the presence of the state that resulted from the event of the fish dying (Izutsu 2004: 25). At the same time, however, the verb could still be understood as referring to the presence of the subject entity in the resultant state evoked by the converb. Thus, the event conception encoded in the aspectual form can be regarded as the moving-event as well as moving-participant type (for this point, see the argument in 5.3 below).

Likewise, Ryukyuan form R1 can have any of the progressive, resultative, and perfect senses, as exemplified in (17). The progressive sense, illustrated in (17a), presupposes that the unexpressed subject referents (fish) are participating in the event of swimming, while the resultative sense, as in (17b), that the participants in the event of dying (cicadas) are present in the resultant state. The perfect sense, as in (17c), does not entail the presence of the event participant (the old man) but the resultant state of his being dead (his absence in the world). 
(17) a. muuru genkisi 'wiizy-oon. (R1: progressive)

all lively swim:CONV-TOP:be.present

'All (the fish) are lively swimming.'

(Gishi 2013: 7)

b. haci 'nzyasuru tuci ya 'uukata maac-oon. (R1: resultative) spit put.out time TOP most die:CONV-TOP:be.present

'When (I) spit them out, they are mostly dead.'

(Gishi 2013: 17)

c. Kanida nu tanmee ya yukusi naa maac-oon. (R1: perfect) Kaneda GEN grandpa NOM desire:by already die:CONV-TOP:be.present 'Old Kaneda, (dying) from greediness, is dead.'

(Gishi 2013: 369)

The existential verb un, included in -oon < -ya-un (Handa 1999: 430), can be viewed as denoting the presence of the event participant in the event itself (progressive sense) or its resultant state (resultative sense). In the perfect sense, the verb refers to the presence of the resultant state. The event conceptions in the progressive and resultative senses can be regarded as the moving-participant type, whereas that in the perfect sense can, as the moving-event type.

Ryukyuan and Japanese forms R1 and J1 can be seen as being grammaticalized because they are accompanied by "semantic changes attendant on "the preserved sense of presence amounts to "less flesh-out of meaning" (p. 393) with "preservation of imageschematic structure" (p. 392), while the development of three senses in the same form corresponds to "the meaning of new domain" (p. 393). The aspectual forms can also be viewed as exhibiting a degree of grammaticization in that R1 always, and J1 often, undergoes phonetic reduction, specifically "reduction of vowels" (Bybee et al. 1994: 107): $\mathrm{V}(t[c / d])-y a-u n>\mathrm{V}(t[c / d])-o o n ; \mathrm{V}-t[d] e-i r u>\mathrm{V}-t[d] e-r u$.

Unlike the Japanese and Ryukyuan forms (J1 and R1), Korean form K1 can carry either a progressive or resultative sense, as illustrated in (18a-c), but not a perfect sense, as shown in (19a) below. 
a. geu-neun os-eul ib-go issda. (K1: progressive/resultative)

he-TOP clothes-ACC wear-CONV be.present

'He is putting on clothes.'

'He is wearing clothes.

(Lee 1993: 191)

b. geu-neun pyeonji hanjang-eul sseu-go issda. (K1:progressive) he-TOP letter one:CL-ACC write-CONV be.present 'He is writing a letter.'

(Lee 1993: 184)

c. geu-neun pyeonji-reul sseo noh-go issda. (K1: resultative) he-TOP letter-ACC write:CONV put-CONV be.present 'He has written a letter.'

(Lee 1993: 188)

Lee (1993: 184) notes:

In one reading, sentence (9) [(18a) here] means that the subject is in the process of putting his clothes on. In another reading, it means that the subject finished putting on the clothes and he is in the resulting state of wearing the clothes.

Following this description, the existential verb issda in the Korean aspectual form can be viewed as denoting the presence of the subject referent in the resultant state, rather than the presence of the state. Such a view suggests that the event conception encoded in the form instantiates the moving-participant rather than moving-event type. It is further endorsed by the fact that the form K1 as well as K2 cannot be ordinarily used for a perfect sense, as seen from the unnaturalness of sentences in (19a); the same content will become an appropriate discourse if the aspectual forms are replaced by simple past forms in V-a[(y)eo]-ss(da), as in (19b) (Yongtaek Kim, personal communication).

a. ??geu saram-eun 1800-nyeon-e taeeona-issda. (K2) 
that person-TOP 1800-year-at be.born.CONV-be.present

??geurigo neujeo-do 1900-nyeon-e jug-eo-issda. (K2)

and.then be.late-too 1900-year-at die-CONV-be.present

??geun-neun eoneu ddae ireohge malha-go-issda. (K1)

he-TOP which time this.way say-CONV-be.present

'He was born in 1800. And then he died, at latest, before 1900. He (had) once said this.'

b. geu saram-eun 1800-nyeon-e taeeona-ssda. (past form)

that person-TOP 1800-year-at be.born.CONV-PST

geurigo neujeo-do 1900-nyeon-e jug-eo-ssda. (past form)

and.then be.late-too 1900-year-at die-CONV-PST

geun-neun eoneu ddae ireohge malhae-ssda. (past form)

he-TOP which time this.way say.CONV-PST

'He was born in 1800 . And then he died, at latest, before 1900. He (had)

once said this.'

What the Korean aspectual forms convey is not the presence of the relevant event or its resultant state but that of a participant in the event or resultant state. Therefore, the Korean forms can be recognized as instantiating the moving-participant rather than moving-event type of event conception.

\section{A typological and cross-linguistic perspective on aspectual event conceptions}

\subsection{Dominant types of event conceptions in East Asian aspectual forms}

The grouping of senses in the aspectual forms discussed so far can be summarized as in Table 3. Based on the range of senses they can convey, the forms can be classified into four groups. The first includes expression A1, which only has a progressive sense. This sense can be analyzed as a participant's presence in an event and thus viewed as the moving-participant type of event conception. The second group subsumes expressions A2, A3, J2, K2, R2, and R3, which only have a resultative sense. This 
sense can be viewed as a participant's presence or absence in a resultant state and therefore analyzed, again, as the moving-participant type of event conception.

Table 3. Senses of each aspectual form in four East Asian languages (Vi and Vt collapsed)

\begin{tabular}{|c|l|l|l|l|}
\hline & \multicolumn{1}{|c|}{ Ainu } & \multicolumn{1}{|c|}{ Japanese } & \multicolumn{1}{|c|}{ Korean } & \multicolumn{1}{c|}{ Ryukyuan } \\
\hline \multirow{2}{*}{$\mathrm{V}_{\text {conv }} \mathrm{V}_{\text {presence }}$} & A1: PROG & J1: PROG/RES/PRF & K1: PROG/RES & R1: PROG/RES/PRF \\
& A2: RES & J2: RES & K2: RES & R2: RES \\
\hline $\mathrm{V}_{\text {conv }} \mathrm{V}_{\text {absence }}$ & A3: RES & - & \multicolumn{1}{|c|}{-} & R3: RES \\
\hline
\end{tabular}

The third group corresponds to K1, which can be used for either a progressive or resultative, not a perfect sense. As just pointed out above, the progressive sense amounts to the conception of a participant's presence in an event. The resultative sense can be appropriately analyzed as the presence or absence of a participant in a state resulting from an event. Both sense can thus be viewed as the moving-participant type of event conception.

The fourth group consists of $\mathrm{J} 1$ and R1, which can be used for any of the progressive, resultative, and perfect senses. Here again, the progressive and resultative senses amount to the conception of a participant's presence in an event and its resultant state, respectively; they can be seen as the moving-participant type of event conception. In contrast, the perfect sense can be viewed as the presence of an event's resultant state rather than that of any participant, let alone the event itself. It is thus analyzable as instantiating the moving-event type of conception.

As noted of (16a) in Section 4.3 above, the existential verb in Japanese form J1 does not agree in animacy with the subject; therefore, it is analyzable as designating the presence of the event encoded in the converb or its resultant state, not of the event participant encoded in the subject. To this extent, the senses of the form $\mathrm{J} 1$ can be seen as being based on the moving-event type of event conception. A similar consideration applies to Ryukyuan form R1. Handa's (1999: 580) explication suggests that the 
existential verb un requires animate subjects, while 'an usually takes inanimate subjects, as is shown in (20):

a. mizi nu neen 'agi ni 'iyu nu иуu-mi?

water NOM be.absent land at fish NOM be.present-Q

'Can there be fish on the land with no water?'

(Handa 1999: 580)

b. kasaa 'a-mi?

umbrella: TOP be.present-Q

'Are there any umbrellas?'

(Handa 1999: 23)

In the progressive and resultative senses of $\mathrm{R} 1$ as well, the verb un can be seen as referring to the presence of the event encoded in the converb or its resultant state rather than its participant. From these considerations, it can be inferred that the progressive and resultative senses of $\mathrm{J} 1$ and R1 may be based on the moving-event as well as moving-participant type of event conception.

As demonstrated thus far, the respective aspectual forms of the four languages have their conceptual bases in the moving-event type or the moving-participant type of event conception (or possibly in both). Table 4 sums up the underlying event-conception type of each aspectual form in the languages.

Table 4. Event conception type of each aspectual form

\begin{tabular}{|l|l|l|l|l|}
\hline & \multicolumn{1}{|c|}{ Ainu } & \multicolumn{1}{c|}{ Japanese } & \multicolumn{1}{|c|}{ Korean } & \multicolumn{1}{c|}{ Ryukyuan } \\
\hline \multirow{2}{*}{$\mathrm{V}_{\text {conv }} \mathrm{V}_{\text {presence }}$} & A1: MP & J1: MP/ME & K1: MP & R1: MP/ME \\
& A2: MP & J2: MP & K2: MP & R2: MP \\
\hline $\mathrm{V}_{\text {conv }} \mathrm{V}_{\text {absence }}$ & A3: MP & - & - & R3: MP \\
\hline
\end{tabular}

(MP: based on the moving-participant conception; ME: based on the moving-event conception)

A brief comparison of the languages may suggest a typological perspective on aspectual event conceptions. One aspectual form in Japanese and Ryukyuan (J1 and 
R1) each inclines to the moving-event type of event conception, while all the other forms are oriented to the moving-participant type of event conception. Whereas the moving-participant type is predominant in the aspectual event conceptions of the four languages, the moving-event type is also more or less dominant in Japanese and Ryukyuan in that each language has one aspectual form whose sense is based on this type of event conception.

Ryukyuan is comparable to Japanese in that R1 and R2 are parallel with J1 and J2 in functional and conceptual terms; the two can be classed as MOVING-EVENT DOMINANT languages because $\mathrm{J} 1$ and $\mathrm{R} 1$ can be based on the moving-event type of event conception. However, Ryukyuan is closer to Ainu in the overall distribution of aspectual forms. In addition to R1/R2 and A1/A2, Ryukyuan and Ainu also have in common an aspectual construction with the existential verb for absence rather than presence, R3 and A3; they can be categorized as ABSENCE-PROMINENT languages. On the other hand, Korean is similar to Ainu in that their aspectual forms are all based on the moving-participant type of event conception. These two languages are classified as MOVING-PARTICIPANT PREDOMINANT languages. As far as the event conceptions of those aspectual forms are concerned, Ryukyuan is closer to Ainu than to Korean, while Japanese is closer to Korean than to Ainu in discord with their geographical relationships. ${ }^{11}$

\subsection{Correlations with phasic event conceptions}

The previous subsection points out that, in terms of aspectual event conceptions, Ryukyuan and Japanese can be classed as MOVING-EVENT DOMINANT languages, Ryukyuan and Ainu can be categorized as ABSENCE-PROMINENT languages, and Korean and Ainu can be classified as MOVING-PARTICIPANT PREDOMINANT languages. However, if phasic conceptions, specifically inceptive and terminative, are taken into account, such a typological picture will vary to a degree. In terms of phasic 
conceptions, all the four languages would appear more to be moving-event dominant rather than moving-participant predominant languages.

In the four languages, one can find some expressions that refer to the beginning (inception) or end (termination) of an event, as illustrated in (21). Some of them manifest themselves as converb constructions like those found in the aspectual forms discussed above, as illustrated in (21c), (21g) and (21i). Other expressions are shaped as a transitive verb preceded by a nominalized/adverbialized complement, as exemplified in (21d-f), (21h), and (21j), while still others take the form of an auxiliary verb with a verbal complement, as instantiated in (21a-b).

(21) a. te wano ku=ye oasi hawe tapan na. (Ainu inceptive) here from I=say start voice this FP

'Now I will start talking.'

(Tamura 1996: 452)

b. ipe $=$ an okere. (Ainu terminative)

eat.meal=I finish

'I finished eating the meal.'

(Tamura 1996: 462)

c. ...aynu ka rayke wa okere wa.... (Ainu terminative) person too kill CONV finish CONV

'...finished killing people and....'

(Nakagawa 1995: 115)

d. ...ike-o hidari-ni mawari-hazime-ta. (Japanese inceptive) pond-ACC left-to go.round-begin-PST

'...(I) began to walk around to the left of the pond.'

(Natsume, Wagahai wa Neko dearu)

e. ...yookan-o tabe-owat-te.... (Japanese terminative) sweet.jelly-ACC eat-finish-CONV

'...(he) finished eating his sweet jelly and....'

(Natsume, Wagahai wa Neko dearu)

f. ...wenjjog-euro dol-gi sijaghae-ssda. (Korean inceptive) 
left.side-to go.round-ing start:CONV-PST

'...(I) began to walk around to the left (of the pond).' (Kim 2006: 9)

g. ...yanggaeng-eul meogeo chiu-go-neun.... (Korean terminative) sweet.jelly-ACC eat-CONV put.aside-CONV-TOP

'...(he) finished eating his sweet jelly and....'

(Kim 2006: 197)

h. ...kumui nu fizyai nkai maai-hazimitan. (Ryukyuan inceptive) pond GEN left to go.round-begin:PST

'...(I) began to walk around to the left of the pond.' (Gishi 2013: 3)

i. ...yookan kadi 'uwati kara.... (Ryukyuan terminative) yokan eat:CONV finish:CONV from

'...(he) finished eating his sweet jelly and....'

(Gishi 2013: 250)

j. ...yooyaku cira 'arai 'uwati.... (Ryukyuan terminative)

finally face wash finish

'...(she) finally finished washing her face and....' (Gishi 2001: 351)

The complement in Korean example (21f) can definitely be regarded as nominal because it can be optionally marked with the accusative case, as in dol-gi-reul (go.round-ing-ACC). The complements in Japanese examples (21d-e), in contrast, can be seen as either nominal or adverbial, although they cannot be marked with the accusative ( ${ }^{*}$ mawari-o hazimeta and "tabe-o owat-te). Whatever construction they can instantiate, the phasic expressions in (21) are mostly centered around transitive verbs. This makes a remarkable difference from the aspectual forms analyzed in Section 4 above, which are founded on intransitive (existential) verbs.

The conceptualizations encoded in the phasic expressions can be largely described as transitive or causative events in which the subject referent initiates or terminates the event encoded in the converb or complement. In such a description, the event rather than its participant is conceived of as moving (Izutsu 1997: 341-342); therefore, the 
inceptive and terminative senses can naturally be regarded as instantiating the movingevent type of event conception.

In the four languages, the inceptive and terminative senses seem more likely to be based on the moving-event than moving-participant type of event conception. In other languages, however, it is far from being rare that those senses are conceptualized in terms of moving-participant conceptions. The English and French sentences in (22) refer to the inception or termination of the event encoded in the complement verb (snowing or putting aside), where the subject referent is envisaged as moving to or from that event.

(22) a. It began [started] to snow.

b. Il commence à neiger. (Oga et al. 1993: 283)

it begin to snow

'It is beginning to snow.'

c. Finissez vite de ranger vos affaires! (Oga et al. 1993: 616) finish fast from put.aside your belonging 'Finish quickly putting aside your belongings!

As Brinton (1988: 113) points out, "verbs expressing 'movement into or towards' or 'connection with' come to mark ingressive aspect, which refers to entry into a situation", while "verbs expressing 'movement out of or away from' or 'separation from' come to mark egressive aspect, which refers to exit from a situation". The terms "ingressive" and "egressive" amount to inceptive and terminative in the present discussion.

The inceptive and terminative expressions in (22) are grounded on the movingparticipant type of event conception, while the Ainu, Japanese, Korean, and Ryukyuan expressions in (21) are far more inclined to the moving-event conceptions. In this regard, the four languages are more likely to count as moving-event dominant 
languages than English and French. However, a further comparison of the expressions shows that the four languages differ in the inclination toward the moving-event conception.

First, oasi (as well as its dialectal variants) in Ainu example (21a) is not attested but in a few dialects (Hattori 1964: 157). Some linguists do not see it as an inceptive but a modal expression that approximates to English will or must (Nakagawa 1982). If viewed from such a standpoint, Ainu will be understood as not having a full-fledged inceptive expression and as adopting such a modal expression for some event conceptions that can be referred to with an inceptive expression in other languages. This understanding implies that Ainu is less inclined to the moving-event type of inceptive conception.

Likewise, chiuda in Korean example (21g) and its near synonym in this phasic use beorida are also items that can hardly be viewed as well-established phasic expressions. Lee (1991: 242) notes that the auxiliary use of beorida "expresses the speaker's regret and/or relief", referring to examples like (23a-b). The event conception encoded in the converb construction with beorida can be recognized as a termination in (23a) but cannot in (23b). A similar account applies to the phasic use of chiuda in (21g).

(23) a. geudeul-i nae gwaja-reul meog-eo beori-eo-ssda. they-NOM my cookie-ACC eat-CONV throw.away-CONV-PST 'To my regret, they ate my cookies.'

'To my relief, they ate my cookies.'

b. geu yeolcha-ga ddeona beori-eo-ssda.

that train-NOM leave.CONV throw.away-CONV-PST

'To my regret, the train left.'

'To my relief, the train left.' 
As is the case with the Ainu inceptive expression, the lack of established terminative expressions suggests that Korean is less inclined to the moving-event type of terminative conception. Ainu and Korean can thus be interpreted as being less inclined to the moving-event type of phasic conception than Japanese and Ryukyuan.

Interestingly, this difference in phasic conceptions can have correlations with the typological perspective on aspectual event conceptions given above: i.e., the (pre)dominance of moving-event/participant conceptions and the prominence of the absence notion in the senses of aspectual forms. Ainu and Korean, all of whose aspectual forms are based on the moving-participant of event conception, are less inclined to the moving-event type of phasic conception; they can be interpreted as being more oriented to the moving-participant type of event conception here as well. In contrast, Japanese and Ryukyuan, whose one aspectual form (J1 and R1) is oriented to the moving-event type of event conception, are much more inclined to the movingevent type of phasic conception.

Ainu and Ryukyuan have an aspectual construction with an existential verb for absence rather than presence, while Japanese and Korean do not. This contrast may account for the observation that Ainu does, but Korean does not, have a well-established terminative expression. Being an absence-prominent language along with Ryukyuan (see the discussion of (15) in Section 4.2 above), Ainu can more easily establish the terminative conception in which the notion of absence plays a central role. The termination of an event amounts to a change into the absence of the event. In Korean, this notion of absence is not prominent in aspectual conceptions, and thus the change into the absence of the event is not so frequently encoded linguistically as the change into the absence of participants is. 


\subsection{Concurrence of moving-event/participant conceptions}

Drawing on Lakoff and Johnson's (1999) distinction between the Location EventStructure and Object Event-Structure metaphors, the present discussion has come up with the basic distinction between the moving-participant and moving-event types of event conceptions. As mentioned in Section 2.1, Lakoff and Johnson (1999: 195) claim that the difference between the two metaphors "can be seen as a figure-ground shift". This implies that the moving-participant and moving-event types of event conceptions would be an instance of figure-ground reversal, and that, if so, one and the same event conception could not presuppose both.

As a matter of fact, the aspectual forms based on one type of event conception usually cannot concur with those based on the other type, as illustrated in (24).
a. ?? sensoo-de hito-ga sin-de i-te i-ru. war-at person-NOM die-CONV be.present-CONV be.present 'There have been being people dying in wars.'
b. ??mado-o ake-te at-te i-ru. window-ACC open-CONV be.present-CONV be.present '(I) have had opened the door.'

In (24a), the moving-participant based sin-de i(-ru) (J1: progressive) does not concur with the moving-event based V-te i-ru (J1: perfect). In (24b), likewise, the movingparticipant based ake-te ar(-u) (J2: resultative) is incompatible with the moving-event based V-te i-ru (J1: perfect).

Phasic expressions, based mostly on the moving-event conception in the four languages, can occur with aspectual forms that are similarly based on the moving-event conception. In (25), for example, the moving-event based kaki-hazime(-ru) and kaki$o e(-r u)$ coincide with the perfect sense of $\mathrm{V}$-te-iru based on the moving-event type of event conception. 
(25) kare-wa nakunaru 3-nen-mae-ni syoosetu-o kaki-hazime-te-iru. he-TOP pass.away 3-year-before-at novel-ACC write-start-CONV-be.present sosite nakunaru 1-nen-mae-ni kaki-oe-te-iru. and.then pass.away 1-year-before-at write-finish-Conv-be.present 'He had started writing a novel three years before he died, and he had finished writing it one year before the death.

However, some phasic expressions based on the moving-event conception can concur with the progressive or resultative sense of Japanese V-te-iru or Korean V-go issda, which is based more on the moving-participant conception, as in (26).

(26) a. hitobito-wa zizitu-o siri-hazime-te-iru.

people-TOP fact-ACC know-start-CONV-be.present

'People are beginning [have begun] to know the fact.'

b. kare-wa sono kizi-o kaki-oe-te-iru.

he-TOP that article-ACC write-finish-CONV-be.present

'He has finished writing the article.'

c. saram-deul-eun sasil-eul al-gi sijagha-go issda.

person-PL-TOP fact-ACC know-ing start-CONV be.present

'People are beginning to know the fact.'

In the event conception of sentences like these, the subject referent is assumed either to bring about (hazime- and sijagha-) the event encoded in the converb/complement and be present in that event, as in (26a) and (26c), or to put out (oe-) the event and be present in the resultant state of the event, as in (26b). Each event conception can be diagramed as in Figures 3 and 4, respectively. Three rectangles in each diagram represent successive scenes that develop from left to right, in which the globe labeled 
"P" stands for the subject referent, the box labeled "E", for the denoted event, and the remnant base of the box labeled "R", for the resultant state of the event.
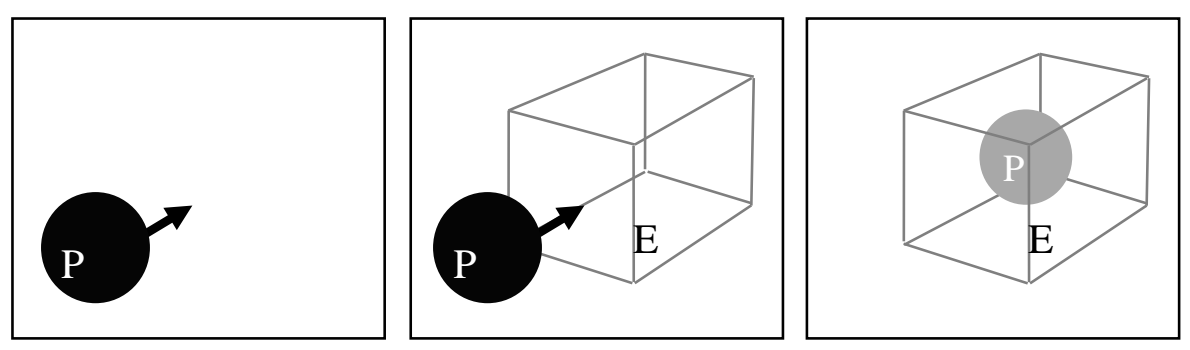

Figure 3. Dual (moving-event/participant) event conception in (26a) and (26c)
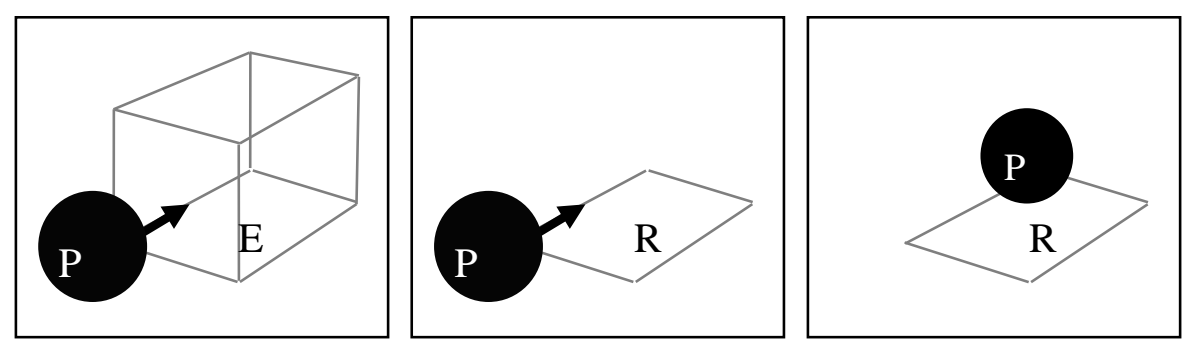

Figure 4. Dual (moving-event/participant) event conception in (26b)

As attested in cases like (26a-c), the moving-event and moving-participant types of event conceptions do concur in one and the same event conception. As far as these concurrences are possible, the two types of event conceptions (pace Lakoff \& Johnson) do not necessarily amount to figure-ground reversals of each other in languages like Japanese and Korean. It may also be a matter of typological variation whether the moving-event and moving-participant types of event conceptions serve as figureground reversals or whether they can be assumed in one and the same conceptualization of event or state.

\section{Conclusion}

This article analyzed the event conception of aspectual expressions in Ainu, Japanese, Korean, and Ryukyuan and proposed a typological perspective in terms of movingevent and moving-participant types of event conceptions. Although these two types 
largely correspond to Lakoff and Johnson's (1999) "Location Event-Structure" and "Object Event-Structure" metaphors, they do not necessarily behave as figure-ground reversals of each other in languages like Japanese and Korean. The article demonstrated that the two types of event conceptions could be presupposed in one and the same conceptualization of event or state.

In the four languages, the moving-participant type of event conception is predominant in the senses of the aspectual forms. Ainu and Korean aspectual forms are all based on the moving-participant type of event conception, while one form in Japanese and Ryukyuan, respectively, is based on the moving-event type. With regard to the senses of phasic expressions, in contrast, the four languages are generally inclined to the moving-event conception. Among them, however, Ainu and Korean are similarly less inclined toward it than Japanese and Ryukyuan. In this respects, too, Japanese and Ryukyuan are analyzable as moving-event dominant languages.

Meanwhile, Ryukyuan is closer to Ainu because these two languages have an aspectual form with an existential verb of absence as well as ones with an existential verb of presence. Korean is similar to Ainu, as just noted above, in that all the aspectual forms of the two languages are based on the moving-participant type of event conception. Interestingly, these affinities are not parallel with the geographical distances among the four languages. Ryukyuan is geographically closer to Japanese than Ainu but aspectually closer to Ainu, while Korean is geographically closer to Japanese than Ainu but aspectually closer to Ainu. This kind of typological perspective on aspectual event conceptions can serve as an intriguing target of further linguistic, cognitive, and anthropological studies.

\section{References}

Asai, T. (1969). Ainugo no bunpoo: Ainugo Ishikari hoogen bunpoo no gairyaku [An Ainu grammar: an overview of the Ishikari dialect]. In Ainu Minzokushi [Ainu 
ethnography]. Ainu Bunka Hozon Taisaku Kyoogikai (ed.). Tokyo: Daiichi Hoki, p. 771-800.

Brinton, L. J. (1988). The development of English aspectual system. Cambridge: Cambridge University Press.

Bybee, J., Perkins, R. \& Pagliuca, W. (1994). The evolution of grammar: tense, aspect, and modality in the languages of the world. Chicago: University of Chicago Press.

Bybee, J.L. \& Dahl, Ö. (1989). The creation of tense and aspect systems in the language of the world. In Studies in Language, 13, p. 51-103.

Chiri, M. (1942). Ainu gohoo kenkyuu: Karafuto hoogen o chuushin toshite [A study of Ainu grammar: with special reference to the Sakhalin dialect]. In Chiri Mashiho Chosakushû [Chiri Mashiho writings], 3. Tokyo: Heibonsha, p. 455-586.

Chomsky, N. (1970). Deep structure, surface structure, and semantic interpretation. In Semantics. Steinberg, D.D. \& Jakobovits, L. A. (eds.). Cambridge: Cambridge University Press, p. 183-216.

Comrie, B. (1976). Aspect. Cambridge: Cambridge University Press.

Freed, A.F. (1979). The semantics of English aspectual complementation. Dordrecht/Boston/London: D. Reidel Publishing Company.

Gishi, M. (2001). Wannee Mayaa du Yaru [I am a cat]. Naha: Shinpo Shuppan. A Ryukyuan translation of the first half of Natsume (1905).

Gishi, M. (2013). Wannee Mayaa du Yaru: Kanketsu hen [I am a cat: conclusive volume]. Naha: Shinsei Shuppan. A Ryukyuan translation of the second half of Natsume (1905).

Givón, T. (1984). Syntax: A functional-typological introduction, Volume I. Amsterdam: John Benjamins.

Givón, T. (1990). Syntax: A functional-typological introduction, Volume II. Amsterdam: John Benjamins.

Handa, I. (1999). Ryuukyuugo Jiten: Naha Shuri o chuushin to suru Okinawa Kooikigo Junkyo [A dictionary of the Ryukyuan language: based on Okinawan dialects of a broader region centered around Naha and Shuri]. Tokyo: Daigaku Shorin. 
Hattori, S. (1964). An Ainu dialect dictionary with Ainu, Japanese and English Indexes. Tokyo: Iwanami.

Izutsu, K. (1997). Phases and their linguistic forms. Doctoral Dissertation. Hokkaido University.

Izutsu, K. (1999). Kyokumen no gainenka yooshiki [Conceptualization patterns of phases]. In Culture and language, 51, Sapporo University, p. 1-27.

Izutsu, K. (2004). Presence of dynamic situations: a comprehensive account of Japanese V-te-i-ru. In Lingua Posnaniensis, 46, p. 21-40.

Jespersen, O. 1949. A modern English grammar on historical principles, vol. 4. London: Allen and Unwin.

Kim, S. (2006). Na neun Goyangi rosoida [I am a cat]. Seoul: Shinsegye Books. A Korean translation of Natsume (1905).

Lakoff, G. \& Johnson, M. 1999. Philosophy in the flesh: The embodied mind and its challenge to Western thought. New York: Basic Books.

Langacker, R.W. (1991). Foundations of cognitive grammar, vol. II: Descriptive applications. Stanford: Stanford University Press.

Langacker, R.W. (2008). Cognitive grammar: A basic introduction. Oxford: Oxford University Press.

Lee, K. (1993). A Korean grammar on semantic-pragmatic principles. Seoul: Hankwuk Munhwasa.

McCawley, J.D. (1971). Tense and time reference in English. In Studies in Linguistic Semantics. Fillmore, C. J. and Langendoen, D.T. (eds.). New York: Holt, Reinhart and Winston, p. 96-113.

Nakagawa, H. (1982). Jodoosh toshite no oasi no yoohoo [An auxiliary use of oasi]. In Ainu Bunka, 7, p. 13-19.

Nakagawa, H. (1995). Ainugo Chitose Hoogen Jiten [A dictionary of Chitose Ainu]. Tokyo: Sofukan.

Natsume, S. (1905). Wagahai wa Neko dearu [I am a cat]. Available at Aozora Bunko: http://www.aozora.gr.jp/cards/000148/files/789_14547.html. 
Nishioka, S. \& Nakahara, J (2000). Okinawago no Nyuumon: Tanosii Uchinaaguchi [An introduction to the Okinawan language: enjoyable Okinawan]. Tokyo: Hakusuisha.

Oga, M., Kaneko, M., Kawatake, H., et al. (1993). Shogakukan dictionnaire FrançaisJaponais. Tokyo: Shogakukan.

Sato, T. (2008). Ainugo Bunpo no Kiso [Basics of Ainu grammar]. Tokyo: Daigaku Shorin.

Shibatani, M. (1990). The languages of Japan. Cambridge: Cambridge University Press.

Shibatani, M. (2003). Directional verbs in Japanese. In Motion, direction, and location in languages: In honor of Zygmunt Frajzyngier. Shay, E. and Seibert, U. (eds.). Amsterdam: John Benjamins, p. 259-286.

Shinzato, R. (1984). Epistemology in Linguistics: A Case Study from Japanese and Okinawan. Doctoral Dissertation. The University of Hawaii.

Smith, C.S. (1991). The Parameter of Aspect. Dordrecht: Kluwer Academic Publishers.

Soga, M. (1983). Tense and Aspect in Modern Colloquial Japanese. Vancouver: University of British Columbia Press.

Sohn, H. (1999). The Korean language. Cambridge: Cambridge University Press.

Tamura, S. (1996). Ainugo Saru Hoogen Jiten [A dictionary of Saru Ainu]. Tokyo: Sofukan.

Sweetser, E. (1988). Gramaticalization and semantic bleaching. In Berkeley Linguistics Society, Proceedings of the Fourteenth Annual Meeting, February 13-15, 1988: General Session and Parasession on Grammaticalization. Axmaker, S., Jaisser A., \& Singmaster, H. (eds.), p. 389-405.

Tomasello, M. (1992). First verbs: A case study of early grammatical development. Cambridge: Cambridge University Press.

Traugott, E. C. 1972. A history of English syntax: A transformational approach to the story of English sentence structure. New York: Holt, Rinehart and Winston. 
Uemura, Y. (1963). Shuri Hoogen no Bunpoo [A grammar of the Shuri dialect]. In Kokuritsu Kokugo Kenkyujo (ed.). Okinawago Jiten [An Okinawan dictionary], p. 5886. The Finance Ministry of Japan.

\section{Notes:}

1. Japanese and Ryukyuan, both spoken in Japan, are now considered to be cognate languages, while Ainu, another language of the northern Japan, and Korean, spoken mainly in the Korean peninsula, are each isolate (Shibatani 1990; Sohn 1999).

2. The following abbreviations are used in the gloss of example sentences:

ACC(usative), ANIM(ate), CL(assifier), CONV(erbalizer), EMPH(asis), F(inal)P(article), GEN(itive), INANIM(ate), NOM(inative), P(a)ST, PL(ural), Q(uestion), QUOT(ative), TOP(ic)

3. In this metaphor, actions are conceptualized as self-propelled movements.

4. Lakoff and Johnson (1999: 148) briefly illustrate the Moving time and Moving Observer metaphors with contrasts like: "Christmas is coming" (Moving Time) vs. "We're coming up on Christmas" (Moving Observer); "That time has passed" (Moving Time) vs. "He passed the time pleasantly" (Moving Observer). In the Moving Time metaphor, "the observer is stationary and time is moving", but in the Moving Observer metaphor, "the observer is moving and time is stationary" (Lakoff \& Johnson 1999: 141).

5. Thus, the perfect construction is infelicitous if the subject referent itself no longer exists, which is often illustrated by an example now well-known for its anomaly interpretation: Einstein has visited Princeton (Chomsky 1970: 212-213; McCawley 1971: 106-108; Comrie 1976: 59-60).

6. The Ainu existential verb of presence an has a suppletive plural form oka(y).

7. The first- and second-person subject and object are marked with pronominal affixes like $k u=$ 'I', en= 'me', $e=$ 'you (sing.)', $a n=$ 'we (incl.)', $i=$ 'us (incl)', $c i=$ 'we (excl.)', 
un= 'us (excl.)', and eci/es= 'you (pl.)'. In contrast, verbs have no pronominal affixes for third-person subject or object marking. See Chiri (1942) for those pronominal affixes and personal forms of verbs in Ainu.

8. The present discussion adopts "=" rather than a hyphen to connect a pronominal affix to a verb or noun in accordance with a commonly used Roman-alphabet notation of the language (cf. Nakagawa 1995; Tamura 1996).

9. Following Uemura's analysis in (1963), Shinzato (1984: 35-37) maintains that een can be used in two different senses: "present resultative" (aspectual sense) and "affirmative past" (evidential sense). She points out that the een form combined with the sentence-final particles doo and yaa denotes a resultative aspect, while the form combined with the particles tee, sa, and yoo denotes affirmative past (1984: 50). It is not clear whether this affirmative past sense approximates the perfect sense in the present discussion or whether it should be treated as an evidential meaning distinguished from aspectual senses in question. In the following examples, kad-ee could either be interpreted as resultative or perfect as well as evidential; in (ii), moreover, kad-ee and kad-oo do not make much difference in meaning (Rumiko Shinzato, personal communication):

(i) 'ari ga du kad-ee sa, 'areeyaasan di yu-ta he NOM EMPH eat.CONV-TOP:be.present FP he:TOP be:hungry QUOT say-PST kutu.

because

'That one must have eaten (it), because he was saying he was hungry.'

(ii) сии уа dateen kad-ee[oo] kutu, yamee today TOP a.lot eat.CONV-TOP:be.present[TOP:be.present] because disease n sugu пооуи sa. too soon be.cured FP

'Since I[you] have eaten a lot today, my[your] disease will soon be cured.' 
Regrettably, the present discussion will not deal with instances interpretable as evidential, which will be dealt with in future studies.

10. Korean form K2 could be used marginally to carry a perfect sense, as in (i), but is still much less unnatural than the past form used in (ii) (Yongtaek Kim, personal communication):

(i) ?Geu-neun sib-nyeon-jeon-e jug-eo issda. he-TOP ten-year-before-at die-CONV be.present

'He (has been dead since he) died ten years ago.'

(ii) Geu-neun sib-nyeon-jeon-e jug-eo-ssda.

he-TOP ten-year-before-at die-CONV-PST

'He died ten years ago.'

11. This typological relationship among the four languages could be diagramed as follows:

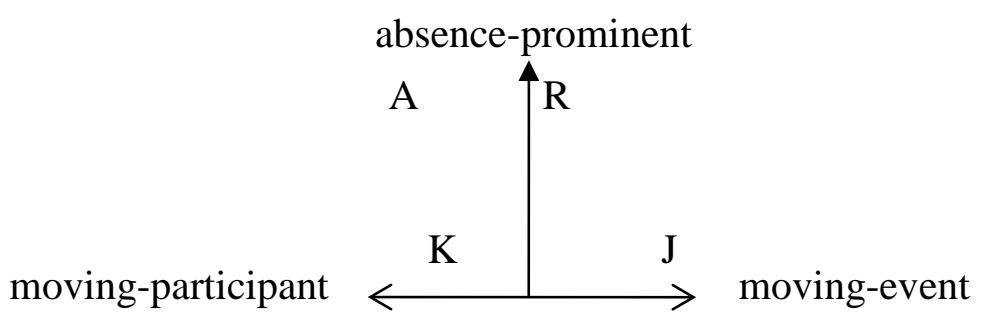

\begin{tabular}{|l|l|}
\hline \multicolumn{1}{|c|}{ Contact data } & \multicolumn{1}{|c|}{ Fields of interest } \\
Katsunobu Izutsu, PhD, & Discourse pragmatics, \\
Associate Professor, & speech-event conception \\
Hokkaido University of & in narrative and \\
Education, 9 chome & conversation, linguistic \\
Hokumoncho, & and cognitive typology, \\
Asahikawa, Hokkaido, & ethnolinguistics, \\
070-8621 Japan & linguistic relativity and \\
e-mail: & universality. \\
idutsuizutsu@outlook.jp & \\
\hline
\end{tabular}




\section{Résumé in English}

This study advances an analysis of the event conception of aspectual forms in four East Asian languages: Ainu, Japanese, Korean, and Ryukyuan. As earlier studies point out, event conceptions can be divided into two major types: the moving-event type and the moving-participant type, respectively. In the moving-participant type, an event is conceived of as a location that a participant comes into or goes out of; in the movingevent type, a participant is viewed as a location, in which an event occurs. In the aspectual conceptions of the four languages, the moving-participant type is predominant. All aspectual forms in Ainu and Korean, and most forms in Japanese and Ryukyuan are based on that type of event conception. In Japanese and Ryukyuan, however, the moving-event type is also dominant, as far as one of the forms in these languages is based on this type of event conception. Unlike the aspectual conceptions, the phasic conceptions of the four languages are largely inclined to the moving-event type of event conception. However, Ainu and Korean are less inclined toward that type than Japanese and Ryukyuan. In this regard as well, Japanese and Ryukyuan can be viewed as moving-event oriented languages. Ainu and Korean aspectual forms put more focus on event participants, whereas Japanese and Ryukyuan forms are more inclined to emphasize the presence of an event or its resultant state rather than that of its participant. The absence as well as presence of an event participant can be focused on in Ainu and Ryukyuan forms, while it is not the case in Japanese and Korean forms. Moving-participant oriented Ainu and moving-event oriented Japanese occupy two extremes, between which Korean and Ryukyuan stand. Notwithstanding the geographical relationships among the four languages, Ryukyuan is closer to Ainu than to Korean, whereas Korean is closer to Ainu than to Japanese.

Keywords: aspect, phase, event conception, Ainu, Japanese, Korean, Ryukyuan. 


\section{Résumé in German}

Diese Studie untersucht die Ereigniskonzeption von Aspektformen in vier asiatischen Sprachen: Ainu, Japanisch, Koreanisch und Ryukyuan. Wie frühere Studien gezeigt haben, gibt es zwei Typen der Ereigniskonzeption: "bewegendes Ereignis" und "bewegender Teilnehmer". Beim letzteren Typ wird ein Ereignis als Raum konzipiert, in den ein Teilnehmer eintritt oder den ein Teilnehmer verlässt; im bewegenden Ereignistyp wird der Teilnehmer als Raum betrachtet, in dem ein Ereignis auftritt. In den Aspektvorstellungen in allen vier Sprachen ist der Konzeptionstyp, in dem sich der Teilnehmer bewegt, vorherrschend. Alle Aspektformen in Ainu und im Koreanischen und die meisten Formen im Japanischen und Ryukyuan basieren auf diesem Typ der Ereigniskonzeption. Im Japanischen und Ryukyuan ist jedoch der andere Typ auch prominent anwesend, weil es in beiden Sprachen eine Form gibt, die auf diesem Typ der Ereigniskonzeption basiert. Im Gegensatz zu den Aspektvorstellungen neigen die Phasenvorstellungen der vier Sprachen stark zum bewegenden Ereignistyp, Japanisch und Ryukyuan mehr als Ainu und Koreanisch. Auch in dieser Hinsicht können Japanisch und Ryukyuan als Sprachen betrachtet werden, die auf diesen Typ der Ereigniskonzeption orientiert sind. Ainu und Koreanisch fokussieren ihre Aspektformen mehr auf die Ereignisteilnehmer, während Japanisch und Ryukyuan dazu neigen, das Vorhandensein eines Ereignisses oder eines resultierenden Zustandes zu betonen. Im Gegensatz zum Japanischen und Koreanischen kann in Ainu und Ryukyuan die An- oder Abwesenheit eines Teilnehmers fokussiert werden. Ainu (zum bewegenden Teilnehmer neigend) und Japanisch (zum bewegenden Ereignis neigend) besetzen die extremen Positionen auf einem Kontinuum, Koreanisch und Ryukyuan sind dazwischen positioniert. Ungeachtet der geographischen Beziehungen zwischen den vier Sprachen, sind Ryukyuan und Koreanisch näher dem Ainu als dem Japanischen. Ryukyuan ist mehr wie Ainu als wie Koreanisch, während Koreanisch mehr wie Ainu als wie Japanisch ist. 
Stichwörter: Aspekt, Phase, Ereigniskonzeption, Ainu, Japanisch, Koreanisch, Ryukyuan.

\section{Résumé in French}

Cette étude analyse la conception de formes aspectuelles dans quatre langues d'Asie orientale: aïnou, japonais, coréen, et ryukyuan. Comme des études antérieures indiquent, les conceptions d'événement se divisent en quatre types, que cette étude appelle respectivement le type d'événement en mouvement et le type de participant en mouvement. Dans le type de participant en mouvement, un événement est conçu comme un lieu duquel un participant vient ou à partir duquel il sort. Dans le type d'événement en mouvement, un participant est considéré comme un lieu dans lequel un événement se produit. Dans les conceptions aspectuelles des quatre langues, le type de participant en mouvement est prédominant. Toutes les formes aspectuelles en aïnou et en coréen, et la plupart des formes en japonais et en ryukyuan, sont basées sur ce type-là. En japonais et en ryukyuan, cependant, le type d'événement en mouvement est également dominant en ce qu'une forme de chaque langue est basée sur ce type-ci de la conception d'événement. Les conceptions de phase dans les quatre langues, qui diffèrent des conceptions aspectuelles, sont largement enclines au type d'événement en mouvement. Mais l'aïnou et le coréen sont moins enclins au ce type-là que le japonais et le ryukyuan. À cet égard aussi, le japonais et le ryukyuan peuvent être considérés comme langues orientées vers le type d'événement en mouvement. Les formes aspectuelles aïnoues et coréennes mettent davantage l'accent sur quelques participants d'événement, alors que les formes japonaises et ryukyanes sont plus enclines à souligner la présence d'un événement ou de son état résultant que la présence d'un participant. L'absence, ainsi que la présence, peuvent être soulignées en aïnou et en ryukyuan, alors que ce n'est pas le cas pour les formes japonaises et coréennes. L'aïnou orienté au participant en mouvement et le japonais orienté à l'événement en mouvement occupent deux éxtrêmes, entre lesquels le coréen et le ryukyuan sont situés. Malgré les 
différences géographiques entre les quatre langues, le ryukyuan est plus proche de l'aïnou que du coréen, alors que le coréen est plus proche de l'aïnou que du japonais.

Mots-clés: aspect, phase, conception d'événement, aïnou, japonais, coréen, ryukyuan

\section{Résumé in Russian}

Данное исследование анализирует концепции события в аспектуальных формах четырёх восточно-азиатских языков: айнского, японского, корейского и рюкюского. Предшествующие исследования показывают, что концепции события делятся на два основных типа, которые в данном исследовании будут называться типом движущегося события и типом движущегося участника. В типе движущегося участника событие рассматривается как место, в которое приходит участник, или из которого он выходит. В типе движущегося события, участник рассматривается как место, в котором происходит событие. В аспектуальных концепциях четырех рассматриваемых языков тип движущегося участника является преобладающим. Все аспектуальные формы айнского и корейского языков, а также большинство форм японского и рюкюского языков основаны на этом типе концепции события. Кроме того, в японском и рюкюском языках, тип движущегося события также является доминирующим, так как одна из форм в этих языках основывается на данном типе концепции события. В отличие от аспектуальных концепций, фазные концепции четырех языков в значительной степени склонны к типу движущегося события. Тем не менее, айнский и корейский языки менее склонны к этому типу, чем японский и рюкюский языки. Таким образом, японский и рюкюский языки можно рассматривать как языки, ориентированные на концепции движущегося события. В то время как айнские и корейские аспектуальные формы подчёркивают участников события, японские и рюкюские формы более склонны подчеркнуть присутствие события или его результирующее состояние, а не присутствие его участника. Отсутствие, а также присутствие участника события 
может быть подчёркнуто в айнских и рюкюских формах, но этого не наблюдается в японских и корейских формах. Айнский язык, склонный к движущемуся участнику, и японский, склонный к движущемуся событию, представляют собой две крайности, между которыми располагаются корейский и рюкюский языки. Несмотря на географические взаимосвязи между четырьмя языками, рюкюский язык более близок к айнскому языку, чем к корейскому языку, в то время как корейский язык более близок к айнскому языку, чем к японскому языку.

Ключевые слова: аспект, фаза, концепция события, айнский, японский, корейский, рюкюский языки.

Article was received by the editorial board 31.07.16;

reviewed 5.08.16 and 3.09.16.

Similarity Index 2\%. 